\title{
Metabolism of methanesulfonic acid involves a multicomponent monooxygenase enzyme
}

\author{
Timothy P. Higgins, ${ }^{1}$ Margaret Davey, ${ }^{1}$ Jim Trickett, $†$ Don P. Kelly ${ }^{2}$ \\ and J. Colin Murrell ${ }^{1}$
}

\begin{abstract}
Author for correspondence: J. Colin Murrell. Tel: +44 1203 523553. Fax: + 441203523568. e-mail: CM@dna.bio.warwick.ac.uk
\end{abstract}

Department of Biological Sciences ${ }^{1}$ and Institute of Education2, University of Warwick, Coventry CV4 7AL, UK

\begin{abstract}
A novel methylotroph, strain M2, capable of utilizing methanesulfonic acid (MSA) as a sole source of carbon and energy was the subject of these investigations. The initial step in the biodegradative pathway of MSA in strain M2 involved an inducible NADH-specific monooxygenase enzyme (MSAMO). Partial purification of MSAMO from cell-free extracts by ion-exchange chromatography led to the loss of MSAMO activity. Activity was restored by the mixing of three distinct protein fractions designated A, B and C. The reconstituted enzyme had a narrow substrate specificity relative to crude cellfree extracts. Addition of FAD and ferrous ions to the reconstituted enzyme complex resulted in a fivefold increase in enzyme activity, suggesting the loss of FAD and ferrous ion from the multicomponent enzyme on purification. Analysis of mutants of strain M2 defective in the metabolism of $C_{1}$ compounds indicated that methanol was not an intermediate in the degradative pathway of MSA and also confirmed the involvement of a multicomponent enzyme in the degradation of MSA by methylotroph strain M2.
\end{abstract}

Keywords: methylotrophy, methanesulfonic acid (MSA), multicomponent enzyme, $\mathrm{C}_{1}$ metabolism, alkyl sulfonates

\section{INTRODUCTION}

Dimethyl sulfide (DMS) is the principal biogenic organic sulfur compound entering the atmosphere, contributing around $50 \%$ of the total biogenic sulfur flux (Kelly \& Smith, 1990). The majority of DMS entering the atmosphere is produced in the marine environment as a byproduct of dimethylsulfoniopropionate(DMSP) biodegradation (Kiene, 1993). DMSP is a cryo-protectant (Kirst et al., 1991) and an osmolyte (Dickson et al., 1982); it is found in several organisms, including marine macroalgae (Dickson et al., 1982), pelagic phytoplankton (Keller et al., 1989) and cyanobacteria (Visscher \& van Gemerden, 1991). Atmospheric DMS is known to undergo lightand chemical oxidation. The reactions involved have been summarized by Kelly et al. (1993). A major product of these oxidation reactions can be methanesulfonic acid (MSA), a stable strong acid that does not undergo

\section{†Deceased (12 April 1993).}

Abbreviations: DMS, dimethyl sulfide; DMSP, dimethylsulfoniopropionate; $M D H$, methanol dehydrogenase; MSA, methanesulfonic acid; MSAMO, methanesulfonic acid monooxygenase; PQQ, pyrroloquinoline quinone. photochemical oxidation (Andreae, 1986). The MSA produced partitions into the aerosol phase, as well as providing cloud condensation nuclei, and is deposited on the Earth's surface in rain or snow and by dry deposition. Once deposited on the Earth, MSA is thought to undergo biodegradation ultimately to form $\mathrm{CO}_{2}$ and $\mathrm{SO}_{4}^{2-}$, which in turn can be incorporated into DMSP, thus completing part of the biogeochemical organic sulfur cycle (Baker et al., 1991).

The stability of MSA is due mainly to the strength of the $\mathrm{C}-\mathrm{S}$ bond found in all organosulfonate compounds. The $\mathrm{C}-\mathrm{S}$ bond resists normal hydrolysis under acidic or alkaline conditions (Wagner \& Reid, 1931; Biedlingmaier $\&$ Schmidt, 1983). The introduction of sulfonate groups into various chemicals is known to lead to a significant decrease in the biodegradability in comparison to substitution of the chemicals by the corresponding carboxylic group (Leidner et al., 1980). However, both naturally occurring and man-made alkylsulfonates are found in the environment (White \& Russell, 1993). A recent review (Kertesz et al., 1994) discussed the biodegradation of organosulfonates in some detail. Whilst the majority of research has centred on the microbial metabolism of 
alkylbenzene sulfonates (arylsulfonates), where a common theme is the desulfonation of the aromatic ring by direct or indirect oxygenation (Locher et al., 1991; Junker et al., 1994; Kertesz et al., 1994), the biodegradation of aliphatic sulfonates has been somewhat neglected. Chlorella fusca utilizes $\mathrm{C}_{1}-\mathrm{C}_{8}$ primary alkylsulfonates as sole sources of sulfur (Biedlingmaier \& Schmit, 1983; Krauss \& Schmidt, 1987) with MSA being the least well used. Aliphatic sulfonates have also been identified as sole sulfur sources for bacteria isolated from soil and sewage (Cook \& Hütter, 1982), as well as certain enteric bacteria (Uria-Nickelsen et al., 1993a) and some yeasts (UriaNickelsen et al., 1993b). Bacteria have also been isolated which can utilize both primary and secondary alkylsulfonates as the only source of carbon and energy. Thysse \& Wanders (1974) described the degradation of $n$ alkane-1-sulfonates by two strains of Pseudomonas. Biodegradation of a secondary alkylsulfonate has also recently been reported (Quick et al., 1994). In both cases, primary biodegradation is proposed to be by direct desulfonation of the alkyl sulfonate. The mechanism proposed involves the insertion of a hydroxyl group at the $\alpha$-carbon by a monooxygenase enzyme. The product, an unstable intermediate, then undergoes spontaneous rearrangement with subsequent elimination of sulfite. Initial studies on the utilization of MSA as a sole source of carbon and energy by the methylotroph M2 (Baker et al., 1991; Kelly et al., 1994) have also indicated that the initial step involves desulfonation to produce formaldehyde and sulfite. Initial studies with cell-free extracts of strain M2 have identified an enzyme capable of oxidizing MSA in the presence of NADH. The enzyme is cytosolic and is induced in strain M2 only when grown on MSA as sole carbon and energy source (Kelly et al., 1994). The enzyme had a $\mathrm{pH}$ optimum of $7 \cdot 0-7 \cdot 2$, and was stable for several days at $-20^{\circ} \mathrm{C}$; no appreciable loss of activity was observed after 5 weeks at $-70^{\circ} \mathrm{C}$ (J. Trickett \& J. C. Murrell, unpublished observations). The formaldehyde produced is then either assimilated into cell biomass via the serine pathway (Baker et al., 1991), or further oxidized to carbon dioxide via formate to regenerate reductant for biosynthesis and the initial oxidation of MSA (Kelly et al., 1994). To our knowledge, no enzyme capable of oxidizing an aklyl sulfonate by a mono-oxygenolytic type mechanism has been characterized. This paper describes the initial purification and characterization of an MSAmonooxygenase (MSAMO), capable of $\mathrm{C}-\mathrm{S}$ bond fission in the presence of $\mathrm{NADH}$, from methylotroph strain $\mathrm{M} 2$, and also the isolation of mutants of strain M2 lacking the ability to carry out such a reaction.

\section{METHODS}

Materials. Except where otherwise stated, all chemicals were of analytical grade supplied by Aldrich or Sigma.

Growth of the organism and preparation of cell-free extracts. Methylotroph strain M2 (Baker et al., 1991) was cultivated and maintained on mineral salts medium Min E (Kelly et al., 1994). Trace element solution (Tuovinen \& Kelly, 1973) and vitamin solution (Kanagawa et al., 1982) were added only when specifically stated. Carbon substrates were added to give a final concentration of $20 \mathrm{mM}$, unless otherwise stated. For solid media, Difco bacto agar $\left(15 \mathrm{~g} \mathrm{l}^{-1}\right)$ was added to the medium prior to sterilization. To provide the large amounts of biomass required for protein purification studies; a MSA-limited chemostat was set up to provide steady-state biomass of strain M2 (Kelly et al., 1994). Initially, a batch culture of strain M2 was grown in a $5000 \mathrm{ml}$ fermenter (LH210 series) equipped with $\mathrm{pH}$, oxygen and temperature control. A constant temperature of $30^{\circ} \mathrm{C}$ and $\mathrm{pH} 7 \cdot 0$ were used throughout and air was supplied to the fermenter continuously at $1 \mathrm{ml}$ (ml culture) ${ }^{-1} \mathrm{~min}^{-1}$. Medium was pumped into the fermenter at a dilution rate of $0.05 \mathrm{~h}^{-1}$ using a Watson Marlow flow inducer, commenced when the culture reached $\mathrm{OD}_{540} 1.5$ (Shimadzu UV-150-02 spectrophotometer). Cells were harvested by centrifugation $(17000 \mathrm{~g})$ at $4{ }^{\circ} \mathrm{C}$, washed three times with $40 \mathrm{mM}$ Tris $/ \mathrm{HCl}$ buffer, $\mathrm{pH} 7 \cdot 0$, and finally resuspended in the same buffer. The cells were either drop-frozen in liquid nitrogen prior to storage at $-70^{\circ} \mathrm{C}$ or immediately broken by two or three passages through a chilled French pressure cell at $137 \mathrm{MPa}$. Cell debris was removed by centrifugation $(50000 \mathrm{~g})$ for $75 \mathrm{~min}$ at $4{ }^{\circ} \mathrm{C}$ to yield cell-free extract which was immediately used, or dropfrozen in liquid nitrogen and stored at $-70^{\circ} \mathrm{C}$.

Analytical methods. The protein content of cell extracts was determined by the methods of Bradford (1976). SDS-PAGE analysis of cell extracts and protein fractions was carried out on $12 \%(\mathrm{w} / \mathrm{v})$ acrylamide gels. Low molecular mass protein standards (Pharmacia Biotech), composed of phosphorylase $b$ (94000 Da), BSA (67000 Da), ovalbumin (43000 Da), carbonic anhydrase (30000 Da), soyabean trypsin inhibitor (20100 Da) and $\alpha$-lactalbumin (14400 Da), were used to calibrate these gels. Immunoblotting (Towbin et al., 1979) was carried out using a Gradipore electroblotting system and Hybond $\mathrm{C}$ nitrocellulose (Amersham). Antibody to methanol dehydrogenase (MDH) from Metbylobacterium extorquens AM1, was kindly supplied by Professor C. Anthony.

Whole-cell oxygen electrode studies. Oxygen electrode studies were carried out by the method described by Kelly et al. (1994); however, only $20-30 \mathrm{mg}$ dry weight of washed cells were used in each experiment and the change in oxygen uptake was determined after the addition of $1 \mathrm{mM}$ (final concentration) of each substrate.

Enzyme assays. A modification of the spectrophotometric assay for measuring MSA monooxygenase activity was used, based on monitoring the substrate-stimulated oxidation of $\mathrm{NADH}$ at $340 \mathrm{~nm}$ (Kelly et al., 1994) where $2 \mathrm{nmol} \mathrm{FAD} \mathrm{and}$ $100 \mathrm{nmol} \mathrm{Fe}\left(\mathrm{NH}_{4}\right)_{2}\left(\mathrm{SO}_{4}\right)_{2}$ were also added to the reaction mixture ( $1 \mathrm{ml}$ final volume). A microtitre plate assay was also used for rapid screening of MSAMO activity in column fractions and of mutants. This assay was based on the detection of sulfite produced following MSA oxidation. The sulfite was detected qualitatively using Ellman's reagent [5,5'-dithiobis(2nitrobenzoic acid)] which produces a yellow colour on reaction with sulfite (Johnston et al., 1975). Assays were carried out in microtitre plates with a final volume of $200 \mu \mathrm{l}$ in each well. Each assay contained $25 \mu \mathrm{l}$ NADH $(10 \mathrm{mM}), 25 \mu \mathrm{l}$ MSA $(50 \mathrm{mM})$, $25 \mu$ l Ellman's reagent $\left(1 \mathrm{mg} \mathrm{ml}^{-1}\right.$ in $100 \mathrm{mM}$ phosphate buffer $\mathrm{pH} 7 \cdot 0$ ) and $20 \mu \mathrm{l}$ of each protein fraction $(10-50 \mu \mathrm{g})$. The reaction mixture was then made up to $200 \mu \mathrm{l}$ with $40 \mathrm{mM}$

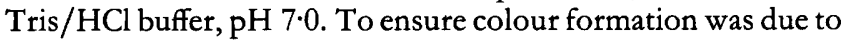
sulfite production and not interference from thiols, controls for each assay were carried out which omitted MSA and replaced it with an equal volume of the same Tris buffer.

$\mathrm{MDH}$ activity was determined by the microtitre plate assay outlined by Day \& Anthony (1990), using $50 \mu \mathrm{g}$ cell-extract 
protein in each assay. All enzyme activities reported are the mean of at least three separate determinations.

Partial purification of MSAMO. Forty millilitres of cell extract (containing approximately $10 \mathrm{mg} \mathrm{ml}^{-1}$ protein) was applied to a pre-packed Q-Sepharose HP 26/20 column (Pharmacia) equilibrated in $20 \mathrm{mM}$ Tris/ $\mathrm{HCl}$ buffer, $\mathrm{pH} 7 \cdot 0$, containing $50 \mathrm{mM}$ $\mathrm{NaCl}$ (buffer A) at $4{ }^{\circ} \mathrm{C}$. The column was washed with $150 \mathrm{ml}$ buffer $A$ to remove unbound proteins from the column. The bound proteins were then eluted by using a $350 \mathrm{ml}$ gradient of increasing $\mathrm{NaCl}$ concentration $(0.05-0.6 \mathrm{M})$ in $20 \mathrm{mM}$ Tris $/ \mathrm{HCl}$ buffer, $\mathrm{pH} 7 \cdot 0$. Fractions $(5 \mathrm{ml})$ were then assayed for MSAMO activity by the microtitre plate assay for convenience. Those showing positive in this assay were then assayed using the spectrophotometric assay. The active fractions were then pooled, drop-frozen in liquid nitrogen and stored at $-70^{\circ} \mathrm{C}$.

Mutagenesis. Mid-exponential phase batch cultures of MSAgrown strain M2 were harvested by centrifugation, and the resultant cell pellets were resuspended in a sufficient volume of sodium acetate buffer ( $\mathrm{pH} 4 \cdot 6$ ) to give a cell suspension equivalent to an $\mathrm{OD}_{540} 1 \cdot 0 . \mathrm{NaNO}_{2}\left(100 \mathrm{mg} \mathrm{m}^{-1}\right)$ was added to the cell suspension (final concentration of $1 \mathrm{mg} \mathrm{m}^{-1}$ ) to produce nitrous acid. Mutagenesis was terminated after incubation with shaking (200 r.p.m.) at $30^{\circ} \mathrm{C}$ for sufficient time (23-25 min) to yield $3-5 \%$ cell survival. Termination of the mutagenesis by nitrous acid was achieved by addition of an equal volume of $40 \mathrm{mM}$ Tris/ $\mathrm{HCl}$ buffer, $\mathrm{pH} 7 \cdot 0$, and rapid centrifugation of the cells. Washed cells were resuspended in $200 \mathrm{ml}$ sterile Min E medium and allowed to recover by incubation with shaking at $30^{\circ} \mathrm{C}$ for $24 \mathrm{~h}$ in the presence of vitamin solution, trace element solution, $20 \mathrm{mM}$ each of MSA, methylamine, formate, and $0 \cdot 2 \%(\mathrm{v} / \mathrm{v})$ methanol. The cells were then subjected to penicillin-enrichment by centrifugation and resuspension in Min $\mathrm{E}$ medium containing vitamin solution, trace element solution, penicillin $\mathrm{G}\left(100 \mu \mathrm{g} \mathrm{ml}^{-1}\right)$ and a single $\mathrm{C}_{1}$ compound ( $20 \mathrm{mM}$ of one of MSA, methylamine or formate or $0.2 \%, \mathrm{v} / \mathrm{v}$, methanol). After incubation, with shaking, of the penicillinenriched cells at $30^{\circ} \mathrm{C}$ for $24 \mathrm{~h}$, the culture was centrifuged and washed in sterile Min E. The cell pellet was then resuspended in sterile $\mathrm{Min} \mathrm{E}$ and diluted to give $10^{3}-10^{4}$ c.f.u. $\mathrm{ml}^{-1}$. Aliquots $(100 \mu l)$ were spread on Min E plates containing vitamin solution, trace element solution and the same carbon source used in the penicillin enrichment and incubated for $7 \mathrm{~d}$. Pinpoint colonies were replica plated onto each of four plates containing Min $\mathrm{E}$ and one of the four $\mathrm{C}_{1}$ compounds, i.e. MSA, methylamine, formate or methanol. Only colonies which were able to grow on two or more of these $\mathrm{C}_{1}$ compounds were selected for further study.

\section{RESULTS}

\section{MSAMO activity and inhibition in cell-free extracts}

Initial studies with freshly-prepared cell-free extracts of MSA-grown strain M2 had revealed an enzyme capable of oxidizing MSA in the presence of NADH (Kelly et al., 1994). MSA-dependent oxidation of NADH also occurred in cell-free extracts of ethanesulfonic acid grown cells of strain M2. However, no such MSA-dependent NADH oxidation was observed in cell extracts of strain M2 when grown on methanol, formate or methylamine as sole sources of carbon and energy indicating that MSAMO was an inducible enzyme and that ethanesulfonic acid is a substrate for the enzyme. The $K_{\mathrm{m}}$ and $V_{\max }$ values for MSA- and ethanesulfonic acid-dependent NADH oxidation by extracts of MSA-grown strain M2 were
Table 1. Substrate specificity for oxidation of NADH in the standard MSA assay

Reaction mixture: $0.04 \mathrm{M}$ Tris $/ \mathrm{HCl} \mathrm{pH} 7.0$ containing $0.4 \mathrm{mM}$ $\mathrm{NADH}$ and $0 \cdot 2-1 \mathrm{mg}$ protein $(50-250 \mu \mathrm{l}$ crude cell-free extract). It was pre-incubated at $30^{\circ} \mathrm{C}$ to determine endogenous oxidation rate then substrate $(5 \mathrm{mM})$ added and substrate-stimulated rate of $\mathrm{NADH}$ oxidation determined.

\begin{tabular}{|lc|}
\hline Substrate & $\begin{array}{c}\text { NADH } \\
\text { oxidation } \\
\text { rate (\%)* }\end{array}$ \\
\hline MSA, sodium salt & 100 \\
Amino-MSA, sodium salt & 36 \\
Ethanesulfonic acid, sodium salt & 79 \\
Propanesulfonic acid, sodium salt & 29 \\
Butanesulfonic acid, sodium salt & 0 \\
Pentanesulfonic acid, sodium salt & 0 \\
Monomethyl sulfate, potassium salt & 94 \\
Dimethyl sulfide & 36 \\
Isethionic acid, sodium salt & 46 \\
Cysteic acid, sodium salt & 23 \\
Taurine, sodium salt & 34 \\
Methylamine hydrochloride & 104 \\
\hline
\end{tabular}

$* 100 \%=58.9 \mathrm{nmol} \mathrm{NADH}$ oxidized $\mathrm{min}^{-1}(\mathrm{mg} \text { protein })^{-1}$.

sufficiently similar to each other [MSA, $48 \mu \mathrm{M}$ and $65.5 \mathrm{nmol} \mathrm{m^{-1 }}$ (mg protein) ${ }^{-1}$; ethane sulfonic acid, $61.5 \mu \mathrm{M}$ and $38.7 \mathrm{nmol} \mathrm{min}^{-1}$ (mg protein) ${ }^{-1}$ ] to indicate oxidation by the same enzyme. Cell extracts also showed increased NADH consumption when challenged with a variety of potential substrates for the enzyme (Table 1). This enzyme activity was stable for several hours at $4^{\circ} \mathrm{C}$. Inhibition experiments were also carried out (Table 2 ) to determine whether the enzyme had associated metal ions, and an associated electron transport system, as is the case with other oxygenases (Mason \& Cammack, 1992). Inhibition of the enzyme by metal chelators (bathophenanthroline, bathocuproine, neocuproine, $\alpha \alpha$ dipyridyl and sodium EDTA) indicated that the enzyme did indeed have associated metal ions which are required for activity. Enzyme activity was also inhibited by the respiratory-chain-inhibitors sodium azide, sodium arsenate and potassium cyanide (Table 2 ), and by bubbling for 1 min with $\mathrm{CO}$, which caused $89 \%$ inhibition, not reversible by further aeration. Electron transfer reactions were thus essential to the reactions producing cleavage of the $\mathrm{C}-\mathrm{S}$ bond of MSA.

\section{Resolution of MSAMO into three active fractions}

Q-Sepharose ion-exchange chromatography was used to separate proteins from cell extract into $5 \mathrm{ml}$ fractions. MSAMO activity was not observed in any individual fraction from the Q-Sepharose chromatography step. However, MSA-dependent sulfite production was restored by adding together three different fractions in the microtitre plate assay. These fractions were designated A, 
Table 2. Effect of inhibitors on MSA oxidation by cellfree extracts of strain M2 as estimated by the spectrophotometric assay

\begin{tabular}{|c|c|}
\hline Inhibitors & $\begin{array}{c}\text { Inhibition } \\
\text { of NADH } \\
\text { oxidation } \\
(\%)^{*}\end{array}$ \\
\hline \multicolumn{2}{|c|}{ Bathophenanthroline } \\
\hline $0.5 \mathrm{mM}$ & 74 \\
\hline $1.0 \mathrm{mM}$ & 89 \\
\hline \multicolumn{2}{|c|}{ Bathocuproine } \\
\hline $0.5 \mathrm{mM}$ & 89 \\
\hline \multicolumn{2}{|c|}{ Neocuproine } \\
\hline $0.5 \mathrm{mM}$ & 15 \\
\hline $1.0 \mathrm{mM}$ & 13 \\
\hline \multicolumn{2}{|c|}{$\alpha \alpha$-Dipyridyl } \\
\hline $1.0 \mathrm{mM}$ & 25 \\
\hline $5 \cdot 0 \mathrm{mM}$ & 31 \\
\hline \multicolumn{2}{|c|}{ Sodium EDTA } \\
\hline $1.0 \mathrm{mM}$ & 28 \\
\hline $5.0 \mathrm{mM}$ & 88 \\
\hline \multicolumn{2}{|c|}{ Sodium azide } \\
\hline $1.0 \mathrm{mM}$ & 66 \\
\hline $5.0 \mathrm{mM}$ & 90 \\
\hline \multicolumn{2}{|c|}{ Sodium arsenate } \\
\hline $1.0 \mathrm{mM}$ & 67 \\
\hline \multicolumn{2}{|c|}{ Potassium cyanide } \\
\hline $0.2 \mathrm{mM}$ & 27 \\
\hline $1.0 \mathrm{mM}$ & 72 \\
\hline
\end{tabular}

* $100 \%$ activity was $58.9 \mathrm{nmol} \mathrm{NADH}$ oxidized $\min ^{-1}$ (mg protein $)^{-1}$.

$\mathrm{B}$ and $\mathrm{C}$, in order of elution from the column (Fig. 1). Fraction $\mathrm{A}$ was red and eluted from the column with $200 \mathrm{mM} \mathrm{NaCl}$. Fraction B was yellow and eluted from the column with $300 \mathrm{mM} \mathrm{NaCl}$. Fraction $\mathrm{C}$ appeared to be colourless and was eluted from the column with $440 \mathrm{mM}$ $\mathrm{NaCl}$, however, subsequent concentration of protein $\mathrm{C}$ by ultrafiltration with an Amicon YM3 membrane resulted in a reddish solution, indicating that the apparent lack of visible absorption was due to the low initial concentration of protein in this column fraction. The requirement of each component for MSAMO activity was confirmed using the standard NADH spectrophotometric assay (Table 3). Addition of $2 \mathrm{nmol} \mathrm{FAD} \mathrm{and} 100 \mathrm{nmol} \mathrm{Fe}^{2+}$ to the reaction mixture [concentrations similar to those used for other oxygenases (Subramanian et al., 1981; Schlafli et al., 1994)] resulted in a fivefold increase in enzyme activity (Table 3), implying both FAD and ferrous ions are required for activity. This has also been observed with other oxygenase enzyme systems (Subramanian et al., 1981; Locher et al., 1991; Schlafli et al., 1994). There was a high endogenous rate of NADH oxidation in the assay when component $\mathrm{B}$ was absent, indicating that component $\mathrm{A}$ or $\mathrm{C}$ was the $\mathrm{NADH}$-binding protein. NADPH could not replace NADH (data not shown), demon- strating that at least in vitro the enzyme was specific for $\mathrm{NADH}$.

\section{Substrate specificity of the three-component MSAMO}

The enzyme reconstituted from the three active components isolated by anion exchange chromatography, unlike crude cell-free extract, was capable of oxidizing only a relatively narrow range of substrates. The enzyme could only oxidize unsubstituted short-chain alkyl sulfonates and compounds of similar structure, MSA $\left[100 \%=113 \mathrm{nmol} \mathrm{NADH}\right.$ oxidized $\mathrm{min}^{-1}$ (mg protein $)^{-1}$, ethanesulfonic acid $(98 \%)$, propanesulfonic acid $(36 \%)$, monomethyl sulfate $(102 \%)$. The reconstituted enzyme was unable to oxidize longer-chain alkyl sulfonates or substituted short-chain alkyl sulfonates, e.g. amino-MSA, butanesulfonic acid, pentanesulfonic acid, isethionic acid, L-cysteic acid or taurine. These results imply some steric hindrance excluding longer-chain alkyl sulfonates and relatively bulky substituted short-chain alkyl sulfonates from the active site of the enzyme. The enzyme did not oxidize methane, DMS, methylsulfoxide, methanethiol, methanol, methylamine, formaldehyde or formate, indicating that the enzyme is indeed specific for short-chain alkyl sulfonates and compounds which are extremely similar in structure. The narrowing of substrate specificity seen on partial purification of the enzyme implied that enzymes that were present in cell extract that are capable of oxidizing compounds such as methylamine had been removed from the partially purified MSAMO complex.

\section{Mutant isolation}

The isolation procedure used in this work exploited a useful property of strain M2, namely its ability to 'scavenge' an unidentified carbon source in Bacto agar, which enabled it to grow slowly on Min $\mathrm{E}$ agar plates without the addition of a carbon source. Under these conditions, colonies produced were approximately $0.1 \mathrm{~mm}$ diameter, compared to colonies of $1-2 \mathrm{~mm}$ diameter observed in the presence of an added carbon source. The pin-point colonies selected during the mutant isolation procedure were assumed to be derived from cells which were unable to use the added carbon source present in the plates. The mutants sought were those in which only the initial reactions in the metabolism of $\mathrm{C}_{1}$ compounds had been affected. To isolate mutants impaired only in the initial oxidation steps, pin-point colonies were replica-plated onto four plates each containing a different $\mathrm{C}_{1}$ carbon source. Only those mutants that could utilize at least two or three different carbon sources were selected for further analysis. The omission of vitamins and trace elements from this step, and subsequent steps in the isolation procedure, mitigated against the selection of the corresponding auxotrophs. After penicillin enrichment, $5-10 \%$ of colonies were of the very small, pin-point type. Further analysis of 1000 putative mutants revealed that approximately $1-2 \%$ of these 


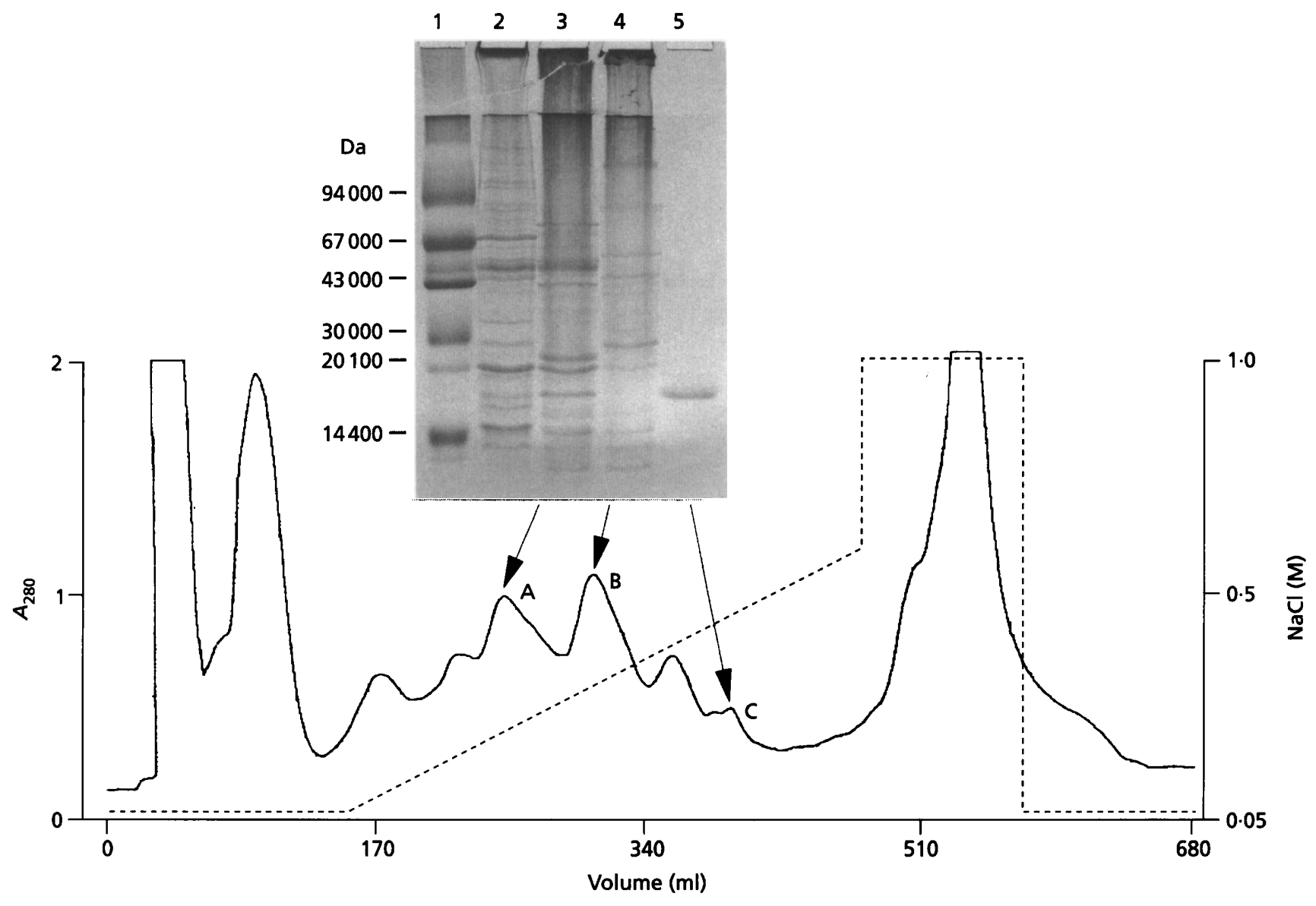

Fig. 1. Separation of components of MSAMO by anion-exchange chromatography. Proteins were eluted with increasing concentrations of $\mathrm{NaCl}$ (dashed line) while monitoring $A_{280}$ (solid line). Comparison of active components with crude cell extracts of strain M2 by Coomassie Blue-stained SDS-PAGE. Lanes: 1, protein standards; 2, cell extracts; 3, component A; 4, component B; 5, component $C$.

colonies were the desired $\mathrm{C}_{1}$ mutants. Six were $\mathrm{MSA}^{-}$ mutants, two were methanol ${ }^{-}$, three were methylamineand two were both $\mathrm{MSA}^{-}$and formate ${ }^{-}$mutants. The growth characteristics of selected mutants (Table 4) were confirmed by growth in liquid culture on $\mathrm{C}_{1}$ carbon sources (MSA, methylamine, formate and methanol) and comparison with the wild-type strain M2.

\section{Characterization of $\mathrm{MSA}^{-}$mutants}

The $\mathrm{MSA}^{-}$mutants (Table 4) were unable to utilize MSA as a sole carbon and energy source in either solid or liquid media. They were able to utilize other $\mathrm{C}_{1}$ compounds (methanol, methylamine and formate) with growth rates similar to that of wild-type strain M2. To ensure that the MSAMO was induced during these growth experiments and subsequent experiments, the mutants and wild-type strain M2 were grown in liquid culture containing $6 \mathrm{mM}$ formate and $20 \mathrm{mM}$ MSA. The formate present allowed sufficient biomass to be produced for analysis. Once all the formate in the culture was utilized, the MSA present could induce expression of MSA enzymes in the cells.
Oxygen electrode studies were carried out to confirm that enzymes which may be involved in the MSA oxidation pathway had been unaffected by the mutagenesis of strain M2. Experiments showed that in contrast to wild-type strain M2, the endogenous oxygen consumption rates of the mutant cells were not stimulated by the addition of MSA, however the mutants responded to the addition of other $C_{1}$ compounds in much the same way as the wildtype strain M2 (Kelly et al., 1994). For example, methanol, methylamine and formate oxidation rates were unaffected. MSAMO activity was not detected in any of the $\mathrm{MSA}^{-}$ mutants by either the microtitre plate assay or the spectrophotometric NADH oxidation assay. In some of the $\mathrm{MSA}^{-}$mutants, MSAMO activity could be restored by 'biochemical complementation' of cell extracts with partially purified components of the enzyme from the wild-type organism (Table 5), suggesting that these mutants may be defective in one or more structural polypeptides of the MSAMO. The mutants that could not be complemented by partially purified components $\mathrm{A}, \mathrm{B}$ or $C$ are either regulatory or transport mutants which inhibit transcription of all the polypeptides required for MSA oxidation. 
Table 3. Spectrophotometric assay of reconstituted MSAMO and effects of the addition of FAD and ferrous ions on enzyme activity

\begin{tabular}{|c|c|}
\hline Reaction mixture & $\begin{array}{c}\text { Activity } \\
\text { [nmol NADH } \\
\text { oxidized } \text { min }^{-1} \\
(\text { mg protein } \\
\text { (-1)] }\end{array}$ \\
\hline Components $\mathrm{A}+\mathrm{B}+\mathrm{C}$ & 26 \\
\hline Components $\mathrm{A}+\mathrm{B}+\mathrm{C}+\mathrm{Fe}^{2+}$ & $18 \cdot 1$ \\
\hline Components $\mathrm{A}+\mathrm{B}+\mathrm{C}+\mathrm{FAD}$ & $80 \cdot 2$ \\
\hline Components $\mathrm{A}+\mathrm{B}+\mathrm{C}+\mathrm{Fe}^{2+}+\mathrm{FAD}$ & 113 \\
\hline Components $\mathrm{A}+\mathrm{B}+\mathrm{Fe}^{2+}+\mathrm{FAD}$ & 0 \\
\hline Components $\mathrm{A}+\mathrm{C}+\mathrm{Fe}^{2+}+\mathrm{FAD}$ & 0 \\
\hline Components $\mathrm{B}+\mathrm{C}+\mathrm{Fe}^{2+}+\mathrm{FAD}$ & $0 \dagger$ \\
\hline
\end{tabular}

* Component A $(50 \mu \mathrm{g})$, component B $(50 \mu \mathrm{g})$, component C $(10 \mu \mathrm{g}), \mathrm{Fe}^{2+}(100 \mu \mathrm{M})$ and FAD $(2 \mu \mathrm{M})$ were added as indicated.

† High endogenous rate.

Table 4. Phenotypes of $C_{1}$ mutants of strain $M 2$ isolated after nitrous acid mutagenesis and penicillin enrichment

Growth measured as $\mathrm{OD}_{540}$ after $72 \mathrm{~h}$ at $30^{\circ} \mathrm{C} .+$, Growth similar to that of wild-type strain M2; - , growth less than $10 \%$ of wild-type strain M2.

\begin{tabular}{|lllll|}
\hline Mutants* & \multicolumn{4}{c|}{ Growth substrate } \\
\cline { 2 - 5 } & MSA & Methanol Methylamine Formate \\
\hline MSA- (6) & - & + & + & + \\
Methanol $^{-}(2)$ & + & - & + & + \\
Methylamine $^{-}(3)$ & + & + & - & + \\
Formate $^{-}(2)$ & - & + & + & - \\
\hline
\end{tabular}

* Numbers in parentheses indicate number of mutants isolated and analysed.

Table 5. Complementation of MSA- mutants with partially purified components of MSAMO measured by the microtitre plate assay

,+ MSA-stimulated sulfite production as indicated by the reaction with Ellman's reagent; - , no sulfite production.

\begin{tabular}{|c|c|c|c|c|}
\hline \multirow[t]{2}{*}{ Mutant } & \multicolumn{4}{|c|}{$\begin{array}{c}\text { Component added to } \\
\text { mutants: }\end{array}$} \\
\hline & None & $\mathbf{A}$ & B & C \\
\hline 1 & - & + & - & - \\
\hline 2 & - & - & - & - \\
\hline 3 & - & - & - & - \\
\hline 4 & - & + & - & + \\
\hline 5 & - & - & - & + \\
\hline 6 & - & - & - & - \\
\hline
\end{tabular}

\section{Characterization of methanol ${ }^{-}$mutants}

The methanol ${ }^{-}$mutants (Table 4) were unable to utilize methanol as sole source of carbon and energy; however, they did utilize other $\mathrm{C}_{1}$ compounds (MSA, methylamine and formate) as did the wild-type strain M2. Oxygen electrode studies using whole cells of the methanol ${ }^{-}$ mutants grown on MSA gave almost identical results to wild-type strain M2 when challenged with MSA, formate and methylamine. The exception was the lack of methanol-stimulated oxygen uptake upon the addition of methanol. MDH activity, as assayed by the method of Day \& Anthony (1990), was also absent in cell extracts of the two methanol ${ }^{-}$mutants. Immunoblot analysis of the methanol ${ }^{-}$mutants compared with wild-type strain M2 showed profound differences. Antibodies to MDH from $M$. extorquens AM1 reacted with the large subunit polypeptide of the MDH (approx. $63 \mathrm{kDa}$ ) in MSAgrown wild-type strain M2 as expected (Fig. 2). However, no proteins in the cell extracts of the methanol mutant- 1 cross-reacted with this antibody. Using cell extracts from the methanol mutant-2, the $\mathrm{MDH}$ antibodies crossreacted with a polypeptide (approx. $65 \mathrm{kDa}$ ) somewhat larger than the large subunit of MDH found in the wildtype strain M2. This indicated that two different mutants had been isolated: a structural mutant which expressed a large subunit of $\mathrm{MDH}$ which differed in size to that of the $\mathrm{MDH}$ in wild-type strain $\mathrm{M} 2$; and a regulatory mutant in which the large subunit was not expressed.

\section{DISCUSSION}

Isolation of mutants which could not utilize methanol as sole carbon and energy source, but which were still able to utilize MSA, supports the proposed MSA oxidation pathway in strain M2 (Kelly et al., 1994), whereby MSA is oxidized directly to formaldehyde and sulfite, but methanol is not an intermediate in the pathway (Fig. 3). The ability of methanol ${ }^{-}$mutants to grow at the expense of MSA confirmed that methanol was not an obligatory intermediate of the MSA degradative pathway in strain M2. Further evidence that methanol was not an intermediate was provided by observations during oxygen electrode studies with wild-type M2. Cyclopropanol, a specific inhibitor of PQQ-dependent MDH (Dijkstra et al., 1984; Higgins et al., 1993), did not inhibit the oxidation of MSA by MSA-grown cells of strain M2, but did inhibit methanol oxidation in the same cells (J. Trickett \& J. C. Murrell, unpublished observations). Elimination of methanol as a potential intermediate of MSA biodegradation, and the production of sulfite by cell extracts of strain M2 is consistent with an oxygenolytic mechanism. This mechanism involves the insertion of a hydroxyl molecule onto the carbon atom by a monooxygenase enzyme to form an unstable intermediate which spontaneously rearranges to produce formaldehyde and sulfite (Fig. 3).

Resolution of the enzyme into three active components is not uncommon among oxygenase enzymes (Green \& 

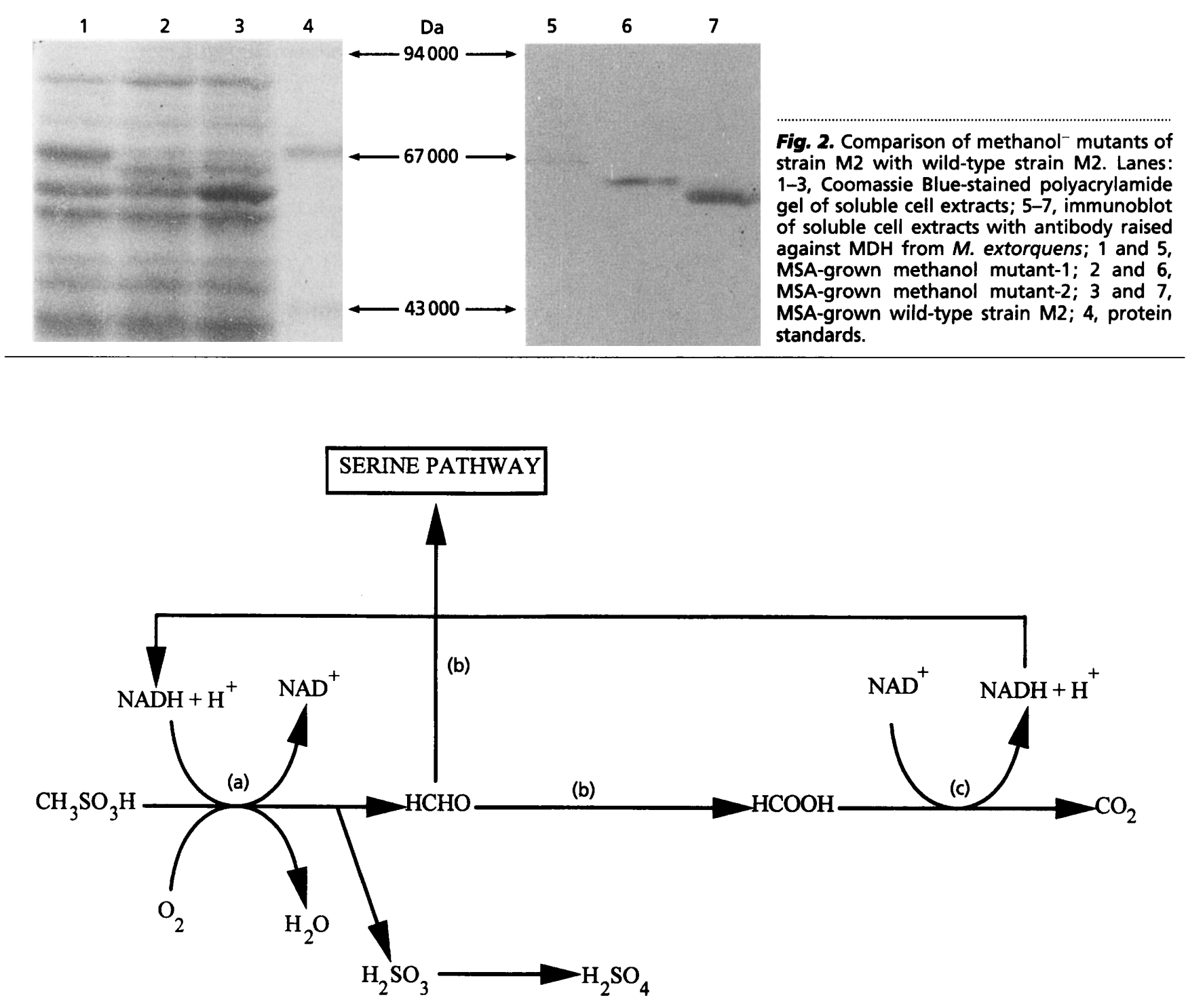

Fig. 3. Proposed pathway for the oxidation of MSA by strain M2 (adapted from Kelly et al., 1994). Key reactions are as follows: (a) an NADH-dependent MSAMO yields formaldehyde and sulfite (which is subsequently oxidized to sulfate); (b) formaldehyde is subsequently assimilated via the serine pathway or is oxidized to formate by formaldehyde dehydrogenase; (c) formate is further oxidized to $\mathrm{CO}_{2}$ by formate dehydrogenase with regeneration of NADH.

Dalton, 1989; Mason \& Cammack, 1992; Powlowski \& Shingler, 1994; Romanov \& Hausinger, 1994). The three-component oxygenases very often have similar features: (i) each has a flavoprotein which acts as an oxidoreductase, catalysing the transfer of two electrons from NADH to the terminal oxygenase component; (ii) the terminal oxygenase contains a transition metal for binding molecular oxygen, and the substrate binding site; (iii) the third component is a small protein which has an alternative role in different oxygenases. It may aid in the transfer of electrons from the flavoprotein to the terminal oxygenase by means of an iron-sulfur cluster, e.g. toluene and naphthalene dioxygenase (Subramanian et al., 1985; Haigler \& Gibson, 1990). In such enzymes, the flavoprotein will still reduce the iron-sulfur protein at the expense of NADH in the absence of the terminal oxygenase component. In other three-component oxygenases such as methane monooxygenase, the small protein has no redox active metals or cofactors, and is thought to act as regulatory protein (Lipscombe, 1994) preventing uncoupled NADH oxidation in the absence of substrates. The NADH oxidation observed in the absence of component B of MSAMO (Table 2) implies that component $\mathrm{B}$ is either the terminal oxygenase component or a small regulatory protein. Further purification of the MSAMO will resolve which of these two possibilities is correct. Increased activity of MSAMO upon the addition of FAD and ferrous ions (Table 3) indicated that they are present in the enzyme complex, and are lost during the purification procedure: the loss of cofactors and iron 
during the purification of oxygenases is well documented (Subramanian et al., 1981; Locher et al., 1991; Schlafli et al., 1994).

The narrowing of substrate range upon partial purification of MSAMO raises some interesting questions about the biodegradation of primary aliphatic sulfonates. The failure of the partially purified enzyme to oxidize substituted sulfonates (amino-MSA, isethionic acid, Lcysteic acid or taurine) and sulfonates $>\mathrm{C}_{3}$ indicates that other enzymes are present in cell extracts which can oxidize them, or that the compounds undergo some enzyme processing before MSAMO can utilize them as substrates: for example amino-MSA may undergo NADH-dependent reductive deamination in cell extracts :

$$
\begin{aligned}
\mathrm{NH}_{2}-\mathrm{CH}_{2}-\mathrm{SO}_{3} \mathrm{H}+\mathrm{NADH}+\mathrm{H}^{+} \rightarrow & \mathrm{NH}_{3} \\
& +\mathrm{CH}_{3}-\mathrm{SO}_{3} \mathrm{H}+\mathrm{NAD}^{+}
\end{aligned}
$$

Butane- and pentanesulfonic acids may undergo $\omega$ oxidation to shorten the chain-length of the molecules prior to oxidation by MSAMO in cell extracts. Studies on the biodegradation of medium- and long-chain alkyl sulfonates $\left(\mathrm{C}_{4}-\mathrm{C}_{12}\right)$ proposed mono-oxygenolytic attack at the $\alpha$-carbon (Thysse $\&$ Wanders, 1974). These studies also indicated that enzymes with differing substrate specificities oxidized the medium- and long-chain sulfonates, respectively. The ability of MSAMO to desulfonate only short-chain sulfonates suggests that metabolism of primary aliphatic sulfonates by different enzymes may be carbon-chain-length-dependent. Interestingly, biodegradation of a similar group of compounds, the primary alkyl sulfates, show similar patterns (Cloves $e$ t al., 1980; Bateman et al., 1986; White et al., 1987; Higgins et al., 1993; Matts et al., 1994). The existence of distinct enzymes for the degradation of short-, medium- and longchain alkyl sulfates is thought to be due to the hydrophobic contributions of the alkyl chains to enzymesubstrate interactions (Matts et al., 1994). Thus, the alkyl chains of medium- and long-chain alkyl sulfonates may not only sterically hinder them from accessing the active site of MSAMO, but may also confer incorrect enzymesubstrate interactions at the active site and thus prohibit their oxidation by MSAMO.

The $\mathrm{MSA}^{-}$structural/functional mutants isolated could be due to a nonsense mutation in one or more of the genes encoding polypeptides of the MSAMO, so that the enzyme is lacking in one or more of the oxygenase components required for activity. Another possibility is that the genes encoding MSAMO are not clustered and thus a mutation has only knocked out a single component of the oxygenase enzyme. The $\mathrm{MSA}^{-}$regulatory mutants isolated are probably caused by mutations in the promoter site or some other regulator, thus inhibiting transcription. Another possibility is that they may be transport mutants in which the transport of MSA into the cells may be affected, thus inhibiting the induction of the enzyme. SDS-PAGE analysis of the mutants (data not shown) demonstrated the absence of all the putative MSAMO polypeptides in the regulatory mutants. Presence of some, but not all, of the putative MSAMO polypeptides was observed in the structural/functional mutants to which activity could be restored by the addition of partially purified components of the enzyme complex. The isolation of both structural and regulatory mutants of MSA metabolism facilitates their use in future studies concerning the regulation of MSA oxidation pathways. These mutants will also be useful for cloning (by complementation of such mutants) of the genes encoding the MSAMO enzyme complex, once systems for gene transfer in strain M2 are established. Interestingly, both formate mutants isolated were also unable to utilize MSA as a sole source of carbon and energy. The isolation of such mutants would indicate that formate oxidation by formate dehydrogenase (Fig. 3) provides a means of recycling NADH utilized by MSAMO, in an analogous situation to growth on methane whereby reduction of $\mathrm{NAD}^{+}$by formate dehydrogenase supplies reductant for the initial oxidation step carried out by methane monooxygenase (Lipscombe, 1994). These double mutants could also be transport mutants lacking the ability to take up both MSA and formate into the cell. The capacity of methylamine mutants to grow on MSA as sole source of carbon and energy, whilst lacking the ability to utilize methylamine suggest that the metabolism of these two $C_{1}$ compounds is distinct (at least up to the point of formaldehyde).

The partial purification of a three-component MSAMO is, to our knowledge, the first reported for an enzyme capable of oxygenolytic cleavage of a $\mathrm{C}-\mathrm{S}$ bond of an alkyl sulfonate. Future studies will concentrate on the purification of the individual components, how these components interact with each other to bring about the NADH-specific oxidation of MSA, and how this MSAinducible enzyme is regulated.

\section{ACKNOWLEDGEMENTS}

We thank the NERC for a research studentship to Margaret Davey and for financial support (Grant no: GR3/8242). We thank Louise Affleck for technical assistance.

\section{REFERENCES}

Andreae, M. O. (1986). The ocean as a source of atmospheric sulfur compounds. In The Role of Air-Sea Exchange in Geochemical Cycling, pp. 331-362. Edited by P. Buat-Menard. New York: Reidel.

Baker, S. C., Kelly, D. P. \& Murrell, J. C. (1991). Microbial degradation of methanesulfonic acid: a missing link in the biogeochemical sulfur cycle. Nature 350, 627-628.

Bateman, T. J., Dodgson, K. S. \& White, G. F. (1986). Primary alkylsulfatase activities of the detergent-degrading bacterium $P$ seudomonas $\mathrm{C} 12 \mathrm{~B}$. Purification and properties of the P1 enzyme. Biochem $J$ 236, 401-408.

Biedlingmaier, S. \& Schmidt, A. (1983). Alkylsulfonic acids and some S-containing detergents as sulfur sources for growth of Chlorella fusca. Arch Microbiol 136, 124-139.

Bradford, M. M. (1976). A rapid and sensitive method for the quantitation of microgram quantities of protein utilizing the principle of protein-dye binding. Anal Biochem 72, 248-254. 
Cloves, J. M., Dodgson, K. S., White, G. F. \& Fitzgerald, J. W. (1980). Purification and properties of the P2 primary alkylsulfohydrolase of the detergent-degrading bacterium Pseudomonas C12B. Biochem J 185, 23-31.

Cook, A. M. \& Hutter, R. (1982). Ametryne and prometryne as sulfur sources for bacteria. Appl Environ Microbiol 43, 781-786.

Day, D. J. \& Anthony, C. (1990). Methanol dehydrogenase from Methylobacterium extorquens AM1. Methods Enzymol 188, 210-215.

Dickson, D. M. J., Wyn Jones, R. G. \& Davenport, J. (1982). Osmotic adaptation in Ulva lactuca under fluctuating salinity regimes. Planta 155 , 409-415.

Dijkstra, M., Frank, J., Jongejan, J. A. \& Duine, J. A. (1984). Inactivation of quinoprotein alcohol dehydrogenases with cyclopropane-derived suicide substrates. Eur $J$ Biochem 140, 369-373.

Green, J. \& Dalton, H. (1989). Substrate specificity of soluble methane monooxygenase. J Biol Chem 264, 17698-17703.

Haigler, B. E. \& Gibson, D. T. (1990). Purification and properties of $\mathrm{NADH}$-ferredoxin ${ }_{\text {NAP }}$ reductase, a component of naphthalene dioxygenase from Pseudomonas sp. strain NCIMB 9816. $J$ Bacteriol 172, 457-464.

Higgins, T. P., Snape, J. R. \& White, G. F. (1993). Comparison of pathways for biodegradation of monomethyl sulphate in Agrobacterium and Hyphomicrobium species. J Gen Microbiol139, 2915-2920.

Johnston, J. B., Murray, K. \& Cain, R. B. (1975). Microbial metabolism of aryl sulfonates. A re-assessment of colorimetric methods for the determination of sulfite and their use in measuring desulfonation of aryl and alkylbenzene sulfonates. Antonie Leeuwenboek 41, 493-511.

Junker, F., Field, J. A., Bangerter, F., Ramsteiner, K., Kohler, H. P., Joannou, C. L., Mason, J. R., Leisinger, T. \& Cook, A. M. (1994). Oxygenation and spontaneous deamination of 2aminobenzenesulfonic acid in Alcaligenes sp. strain 0-1 with subsequent meta ring cleavage and spontaneous desulfonation to 2hydroxymuconic acid. Biochem J 300, 429-436.

Kanagawa, T., Dazai, M. \& Fukuoka, S. (1982). Degradation of O,O-dimethyl phosphorothioate by Thiobacillus thioparus TK-1 and Pseudomonas AK-2. Agric Biol Chem 46, 2571-2575.

Keller, M. D., Bellows, W. K. \& Guillard, R. L. (1989). Dimethyl sulfide production in marine phytoplankton. In Biogenic Sulfur in the Environment, pp. 167-182. Edited by E. S. Saltzman \& W. J. Cooper. Washington, DC: American Chemical Society.

Kelly, D. P. \& Smith, N. A. (1990). Organic sulfur compounds in the environment. Biogeochemistry, microbiology and ecological aspects. Adv Microb Ecol 11, 345-385.

Kelly, D. P., Malin, G. \& Wood, A. P. (1993). Microbial transformations and biogeochemical cycling of one-carbon substrates containing sulfur, nitrogen or halogens. In Microbial Growth on $C_{1}$ Compounds, pp. 47-63. Edited by J. C. Murrell \& D. P. Kelly. Andover: Intercept.

Kelly, D. P., Baker, S. C., Trickett, J., Davey, M. \& Murrell, J. C. (1994). Methanesulphonate utilization by a novel methylotrophic bacterium involves an unusual monooxygenase. Microbiology 140, 1419-1426.

Kertesz, M. A., Cook, A. M. \& Leisinger, T. (1994). Microbial metabolism of sulfur- and phosphorous-containing xenobiotics. FEMS Microbiol Rev 15, 195-215.

Kiene, R. P. (1993). Microbial sources and sinks for methylated sulfur compounds in the marine environment. In Microbial Growth on $C_{1}$ Compounds, pp. 15-33. Edited by J. C. Murrell \& D. P. Kelly. Andover: Intercept.
Kirst, G. O., Thiel, C., Wolff, H., Nothnagel, J., Wanzek, M. \& Ulmke, R. (1991). Dimethylsulfoniopropionate (DMSP) in ice-algae and its possible biological role. Mar Chem 35, 381-388.

Krauss, F. \& Schmidt, A. (1987). Sulphur sources for the growth of Cblorella fusca and their influence on key enzymes of sulphur metabolism. J Gen Microbiol 133, 1209-1219.

Leidner, H., Gloor, R., Wuest, D. \& Wuhrmann, K. (1980). The influence of the sulfonic group on the biodegradability of $n$ alkylbenzene sulfonates. Xenobiotica 10, 47-56.

Lipscombe, J. D. (1994). Biochemistry of the soluble methane monooxygenase. Annu Rev Microbiol 48, 371-399.

Locher, H. H., Leisinger, T. \& Cook, A. M. (1991). 4-Toluene sulfonate methyl-monooxygenase from Comamonas testosteroni $\mathrm{T}-2$ : purification and some properties of the oxygenase component. $J$ Bacteriol 173, 3741-3748.

Mason, J. R. \& Cammack, R. (1992). The electron-transport proteins of hydroxylating bacterial dioxygenases. Annu Rev Microbiol 46, 277-305.

Matts, P. J., White, G. F. \& Payne, W. J. (1994). Purification and characterisation of the short-chain alkylsulfatase of coryneform B1a. Biochem J 304, 937-943.

Powolowski, J. \& Shingler, V. (1994). Genetics and biochemistry of phenol degradation by Pseudomonas sp. CF600. Biodegradation 5, 219-236.

Quick, A., Russell, N. J., Hales, S. G. \& White, G. F. (1994). Biodegradation of sulphosuccinate: direct desulphonation of a secondary sulphonate. Microbiology 140, 2991-2998.

Romanov, V. \& Hausinger, R. P. (1994). Pseudomonas aeruginosa 142 uses a three-component ortho-halobenzoate 1,2-dioxygenase for metabolism of 2,4-dichloro- and 2-chlorobenzoate. J Bacteriol 176, 3368-3374.

Schlafli, H. R., Weiss, M. A., Leisinger, T. \& Cook, A. M. (1994). Terphthalate 1,2-dioxygenase system from Comamonas testosteroni $\mathrm{T}$ 2 : purification and some properties of the oxygenase component. $J$ Bacteriol 176, 6644-6652.

Subramanian, V., Liu, T.-N., Yeh, W.-K., Narro, M. \& Gibson, D. T. (1981). Purification and properties of NADH-ferredoxin ${ }_{\text {rou }}$ reductase. A component of toluene dioxygenase from Pseudomonas putida. J Biol Chem 256, 2723-2730.

Subramanian, V., Liu, T.-N., Yeh, W.-K., Serder, C. M., Wackett, L. P. \& Gibson, D. T. (1985). Purification and properties of ferredoxin $_{\text {TоL }}$. A component of toluene dioxygenase from $P_{\text {seudo- }}$ monas putida F1. J Biol Chem 260, 2355-2363.

Thysse, G. J. E. \& Wanders, T. H. (1974). Initial steps in the degradation of n-alkane-1-sulfonates by Pseudomonas. Antonie Leeuwenboek 40, 25-37.

Towbin, H., Staehelin, T. \& Gordon, J. (1979). Electrophoretic transfer of proteins from polyacrylamide gel to nitrocellulose sheets: procedure and some applications. Proc Natl Acad Sci USA 76, 4350-4354.

Tuovinen, O. H. \& Kelly, D. P. (1973). Studies on the growth of Thiobacillus ferrooxidans. I. Use of membrane filters and ferrous iron agar to determine viable numbers, and comparison of ${ }^{14} \mathrm{CO}_{2}$ fixation and iron oxidation as measures of growth. Arch Microbiol 88, 285-298.

Uria-Nickelsen, M. R., Leadbetter, E. R. \& Godchaux, W., III (1993a). Sulphonate utilization by enteric bacteria. J Gen Microbiol 139, 203-208.

Uria-Nickelsen, M. R., Leadbetter, E. R. \& Godchaux, W., III (1993b). Sulfonate-sulfur assimilation by yeasts resembles that of bacteria. FEMS Microbiol Lett 114, 73-78. 
Visscher, P. T. \& van Gemerden, H. (1991). Production and consumption of dimethylsulfoniopropionate in marine microbial mats. Appl Environ Microbiol 57, 3237-3242.

Wagner, F. C. \& Reid, E. E. (1931). The stability of the carbonsulfur bond in some aliphatic sulfonic acids. $J$ Am Chem Soc 53, 3407-3413.

White, G. F. \& Russell, N. J. (1993). Biodegradation of anionic surfactants and related compounds. In Biocbemistry of Microbial
Degradation, pp. 143-177. Edited by C. Ratledge. Dordrecht: Kluwer.

White, G. F., Dodgson, K. S., Davies, I., Matts, P. J., Shapleigh, J. P. \& Payne, W. J. (1987). Bacterial utilisation of short-chain primary alkyl sulfate esters. FEMS Microbiol Lett 40, 173-177.

Received 4 July 1995; accepted 18 October 1995. 